MATEC Web of Conferences 53, 01021 (2016)

DOI: $10.1051 /$ matecconf/20165301021

(C) Owned by the authors, published by EDP Sciences, 2016

\title{
Master degree in Construction area (main results of the admission company)
}

\author{
Eliza Gumerova ${ }^{1, a}$, Olga Gamayunova ${ }^{1}$, Sofiia Pospelova ${ }^{2}$ \\ ${ }^{1}$ St. Petersburg State Polytechnical University, Polytechnicheskaya, 29, Saint-Petersburg, 195251, Russia \\ ${ }^{2}$ Plekhanov Russian University of Economics (Sevastopol branch), Vakulenchuka st., 29, Crimea, Sevastopol, \\ 299053, Russia
}

\begin{abstract}
Russia enacted a move to two-tier education in line with Bologna Process model more than 10 years ago. Nowadays after the bachelor's degree student can earn a master's degree (usually two years). Master degree programs give advanced knowledge of a specialized body of theoretical and applied topics and prepare graduates for a career in their chosen field. Master degree programs in the field of Construction Engineering are popular among enrollees. The article is about results of the admission to master's degree programs of the Institute of Civil Engineering of Peter the Great Saint-Petersburg Polytechnic University in 2015.
\end{abstract}

\section{Introduction}

Peter the Great St.Petersburg Polytechnic University is the national research facility which was founded in 1899 [1]. SPbPU is one of 15 Russian leading universities who entered the Ministry of Education and Science Program "5-100-2020" [17]. Its aim is to ensure at least 5 Russian universities in the TOP-100 of the world's leading universities according to the QS World University Rankings by 2020 [3].

The Institute of Civil Engineering is the legal successor of the Faculty of Civil Engineering founded in 1907 and considered one of the most respected construction faculties of Russia. The institute aims to prepare managers and leaders of construction companies and designing bureaus, heads of departments, chief engineers of projects, project managers and other highly qualified staff. [4]

Each student has opportunity to go abroad for internship and practice in foreign universities [20]. The institute carries out the "Double Degree" program; after a year training at a foreign partner institution a student receives both Russian and European diplomas at once [21].

Our Institute is proud of its graduates who have made the career of famous builders, scientists, heads of ministries and major politicians.

The Institute of Civil Engineering carries out the admission to the bachelor's degree, master's degree and engineer degree.

The Institute of Civil Engineering has been on the first place in Russia by the average result of the exam of students enrolled the programs in the field of construction engineering for the last 3 years. The Institute has the international accreditation of educational programs.

\footnotetext{
${ }^{\mathrm{a}}$ Corresponding author : eliza_gumerova@mail.ru
} 
The teachers of the Institute are engaged in training and research activities. Some of them are active managers and employees of the leading construction companies of the city [19].

Cooperation with construction companies is one of the foreground directions of the activities in the Institute. The majority of students from the 3rd course have already been working in partnerorganizations of the Institute [13].

\section{Master's degree programs of the Institute of Civil Engineering}

The Institute of Civil Engineering (ICE) carries out the admission to the master's degree programs in two fields of study such as «Construction Engineering» and «Environmental and Water Use». Today the Institute of Civil Engineering offers a wide range of master's degree programs in the field of Construction Engineering and one in the field of Environmental and Water Use (table 1).

Table 1. Master's degree programs of the ICE [5].

\begin{tabular}{|c|c|c|}
\hline Program name & $\begin{array}{l}\text { Code of the } \\
\text { program }\end{array}$ & Program profile \\
\hline \multirow{12}{*}{$\begin{array}{l}\text { 08.04.01 Construction } \\
\text { Engineering }\end{array}$} & 02 & $\begin{array}{l}\text { Marine hydraulic engineering constructions and } \\
\text { constructions of waterways }\end{array}$ \\
\hline & 06 & $\begin{array}{c}\text { Organization and management of construction and } \\
\text { investment projects }\end{array}$ \\
\hline & 08 & Construction of landscape architecture facilities \\
\hline & 10 & Computer-aided design of buildings and structures \\
\hline & 11 & Engineering systems of buildings and structures \\
\hline & 12 & $\begin{array}{c}\text { Civil Engineering (master's degree program in } \\
\text { English) }\end{array}$ \\
\hline & 13 & $\begin{array}{c}\text { Design, construction and management of renewable } \\
\text { energy facilities }\end{array}$ \\
\hline & 14 & $\begin{array}{c}\text { Energy Efficient and Sustainable Buildings (master's } \\
\text { degree program in English) }\end{array}$ \\
\hline & 15 & $\begin{array}{c}\text { Innovative methods of design and construction of } \\
\text { hydraulic structures }\end{array}$ \\
\hline & 16 & $\begin{array}{l}\text { Design and construction of facilities of the housing } \\
\text { and public utility sector }\end{array}$ \\
\hline & 17 & Urban Construction and Economy \\
\hline & 18 & Environmental engineering protection in construction \\
\hline
\end{tabular}




\begin{tabular}{|c|c|c|}
\cline { 2 - 3 } & 19 & Survey and technical audit of buildings and structures \\
\cline { 2 - 3 } & 20 & $\begin{array}{c}\text { Technology of calculation, design and construction of } \\
\text { industrial and civil buildings and structures with the } \\
\text { use of modern software }\end{array}$ \\
\hline $\begin{array}{c}20.04 .02 \text { Environmental and } \\
\text { Water Use }\end{array}$ & Landscape arrangement of the territory \\
\hline
\end{tabular}

\section{International master's degree programs (in English)}

Nowadays there are two international master's degree programs in the Institute of Civil Engineering: 08.04.01.12 «Civil Engineering» and 08.04.01.14 «Energy Efficient and Sustainable Buildings». Training in international groups allows to improve knowledges of the English language, to get acquainted and learn more about other cultures of foreign students [4].

Graduates will get experience and practical skills in the field of Civil Engineering in the key subjects of structural and hydraulic engineering, project management and design. Major areas of expertise [10]:

- Structural design and analysis;

- Building services and facilities;

- Capital Investment Planning;

- Building Information Modeling skills;

- Energy efficient solutions;

- Construction Project Management;

- Publishing and scientific Research work.

The following teaching methods are applied to deliver the pertinent knowledge in civil engineering and to develop practical skills in the most efficient way [4]:

- Lectures and discussions. A lecturer explores a problem on a relevant topic to be considered and studied in a detailed way. Students are welcome to ask any pertinent questions at the end of a lecture.

- Seminars. A lecturer provides general guidance for a group working on an advanced study or research project. This approach is aimed at exchanging information and developing new solutions to problems under study by the group.

- Study assignments. This method is implied to orient students to a topic prior to classroom or laboratory work. Students are normally asked to read periodicals or any relevant teaching materials, to do some research work or to exercise for more practice.

- Demonstration. This method implies actual performing an operation or doing a job which shows students what to do and how to do it. Students might get valuable empirical knowledge in the field of expertise and develop vocational skills.

- Scientific research activities and publishing. These activities imply working in research labs as well as writing scientific articles under a professor's supervision. Students can get their research and scientific articles published on global citation websites.

- Brainstorming and role plays. These approaches make it possible for a lecturer to engage students in teamwork and to stimulate more active participation in order to fix the knowledge acquired during studies.

Major areas of program «Energy Efficient and Sustainable Buildings»:

- Up-to-date energy efficient technologies and solutions

- Civil engineering insights;

- Structural design and analysis;

- Construction Projects Management in the context of energy efficiency and sustainability;

- Investment and Budgeting of energy efficient buildings;

- Publishing and scientific research work.

Key Points of program «Energy Efficient and Sustainable Buildings»: 
- individual approach and on-going assistance;

- $\quad$ online distance learning using MOODLE (www.dl.spbstu.ru) [9];

- communication with experts from leading construction and engineering companies;

- scholarships to study abroad in English in one of the European partner universities (a semester or a summer school)

- the course is fully taught in English;

- $\quad$ scientific research activities, regular participation in seminars, conferences and forums;

- joint projects and research activities with teachers' engagement;

- using advanced computer technology in construction;

- online communication between students and teachers via intranet web-site based on MOODLE system.

\section{Results and Discussion}

Each student should pass Multiple Choice Test in a relevant field of studies to be enrolled for Master's Degree Programs. The Institute of Civil Engineering ranked first on admission to training engineers, bachelor and master degrees in the field of Construction Engineering on budgetary basis in the Northwestern Federal District (table 2).

Table 2. Plan of the admission to baccalaureate, specialty, magistracy in the field of Construction Engineering in the universities in the Northwestern Federal District (2015).

\begin{tabular}{|c|c|c|c|c|}
\hline & $\begin{array}{c}\text { ICE } \\
(\text { SPbPU) }\end{array}$ & $\begin{array}{c}\text { SPbGASU } \\
{[6]}\end{array}$ & $\begin{array}{c}\text { The National Mineral } \\
\text { Resources University [7] }\end{array}$ & $\begin{array}{c}\text { St. Petersburg State } \\
\text { University of } \\
\text { Communication [8] }\end{array}$ \\
\hline $\begin{array}{c}\text { Academic } \\
\text { baccalaureate } \\
\text { («Construction } \\
\text { Engineering») }\end{array}$ & 198 & 150 & - & - \\
\hline $\begin{array}{c}\text { Practical } \\
\text { baccalaureate } \\
\text { («Construction } \\
\text { Engineering») }\end{array}$ & - & 150 & - & - \\
\hline $\begin{array}{c}\text { Specialty } \\
\text { («Construction of } \\
\text { Unique Buildings and } \\
\text { Constructions») }\end{array}$ & 57 & 40 & - & - \\
\hline $\begin{array}{c}\text { Magistracy } \\
\text { «Construction } \\
\text { Engineering» }\end{array}$ & 200 & 80 & - & 17 \\
\hline
\end{tabular}

In table 3 there are results of the admission to master's degree programs in full-time or correspondence form of education in 2015.

Table 3. Results of the admission to master's degree programs of the Institute of Civil Engineering in 2015.

\begin{tabular}{|l|l|l|l|l|}
\hline \multirow{2}{*}{} & \multicolumn{2}{|c|}{ Construction Engineering } & \multicolumn{2}{c|}{ Environmental and Water Use } \\
\cline { 2 - 4 } & Full-time form & Correspondence form & Full-time form & $\begin{array}{c}\text { Correspondence } \\
\text { form }\end{array}$ \\
\cline { 2 - 4 }
\end{tabular}




\begin{tabular}{|c|c|c|c|c|}
\hline $\begin{array}{c}\text { Plan of the } \\
\text { admission }\end{array}$ & 200 & 60 & 20 & - \\
\hline $\begin{array}{c}\text { Quantity of } \\
\text { submitted } \\
\text { applications }\end{array}$ & 274 & 38 & 14 & - \\
\hline
\end{tabular}

The quantity of submitted applications are graduates from more than 10 universities of Russia and foreign countries. Nevertheless, the main part of enrolees completed the bachelor degree at SPbPU $(42 \%)$ and SPbGASU (24\%) (fig. 1$)$.

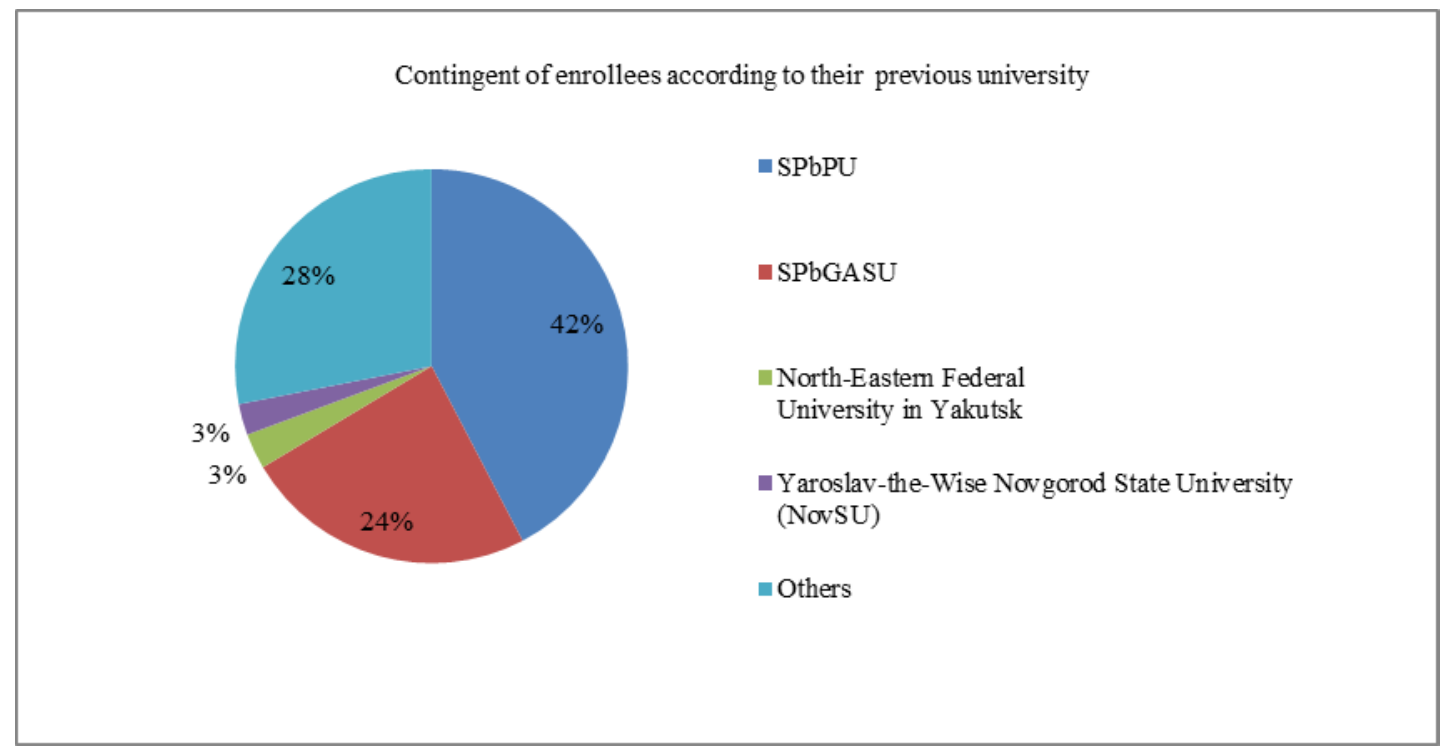

Figure 1. Contingent of enrollees according to their previous university.

Information about the master's profile program and the plan of admission is on the figure 2 . The competition is based on the profile that was listed as prior to others in the application. There are five profile programs that are popular among enrollees:

- 08.04.01.06 «Organization and management of construction and investment» (competition 1.92)

- $\quad$ 08.04.01.10 «Computer-aided design of buildings and structures» (competition - 2.67)

- $\quad$ 08.04.01.12 «Civil Engineering» (competition - 2.1)

- 08.04.01.17 «Urban Construction and Economy» (competition - 3.92)

- $\quad$ 08.04.01.20 «Technology of calculation, design and construction of industrial and civil buildings and structures with the use of modern software» (competition - 1.75) 


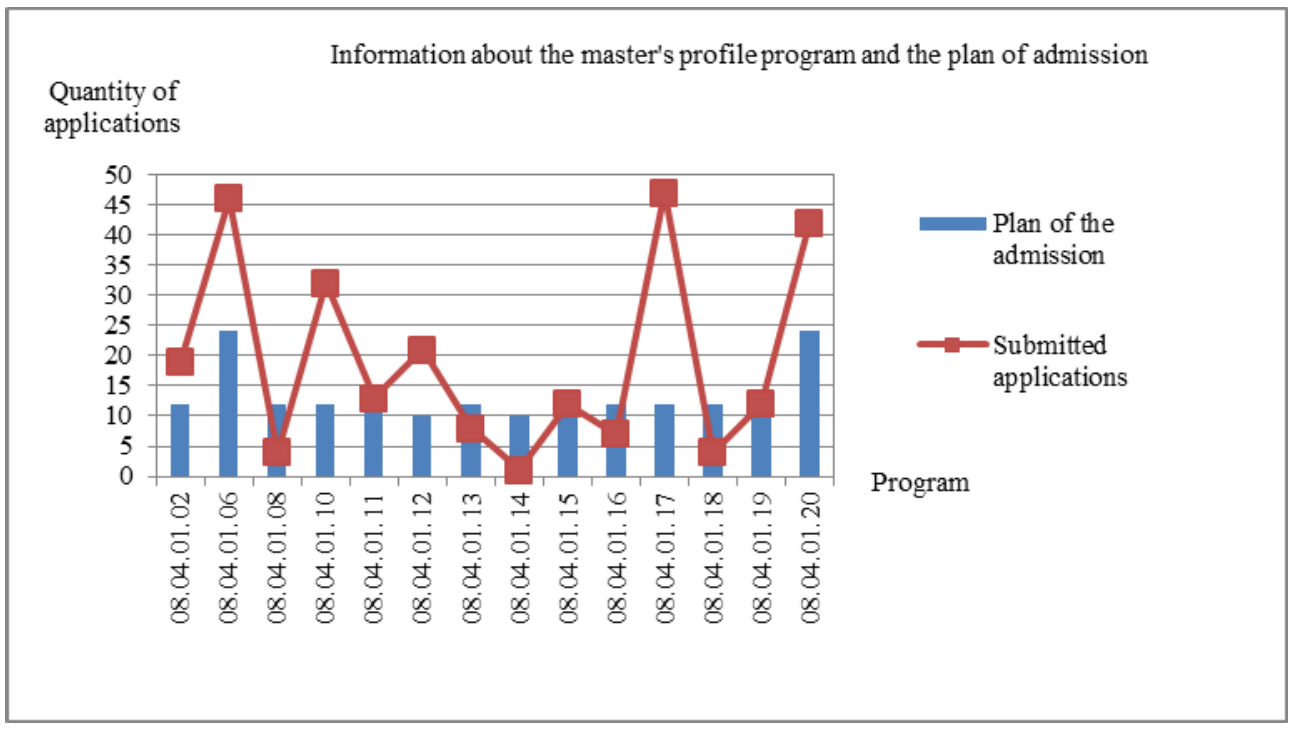

Figure 2. Information about the master's profile program and the plan of admission.

The vast majority of bachelors with the diploma with honors successfully passed the exam and entered the magistracy of the Institute of Civil Engineering. 77\% and $63 \%$ of enrollees were enlisted to master's degree programs in full-time and in correspondence form of education in 2015. (Fig.3)

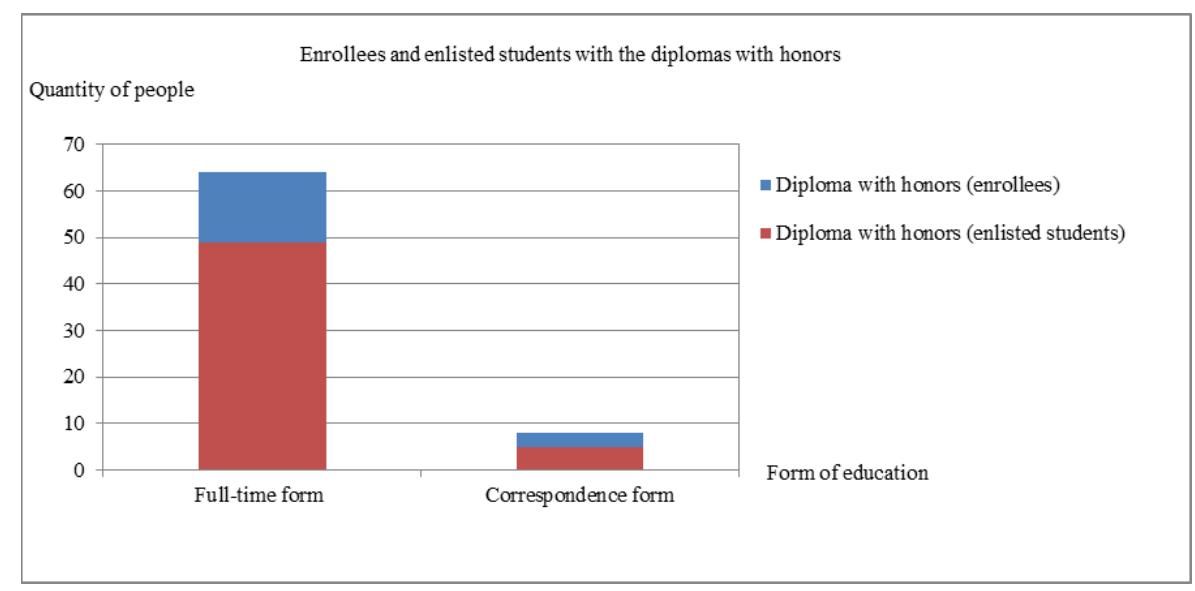

Figure 3. Enrollees and enlisted students with the diplomas with honors.

The percentage ratio of enrollees with the diplomas with honors depends on their previous place of study. Mostly, there are graduates from SPbPU (38\%) and SPbGASU (16\%). (Fig.4) 
The percentage ratio of enrollees with the diplomas with honors depends on their previous place of study

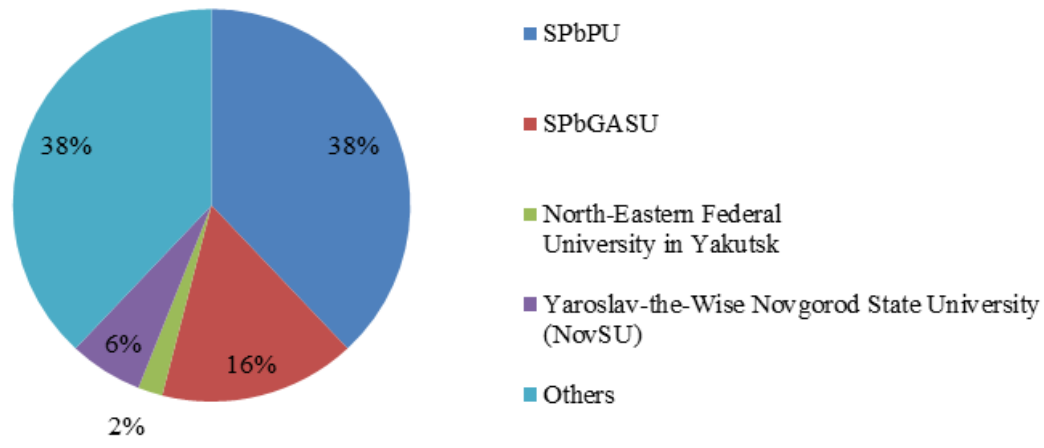

Figure 4. The percentage ratio of enrollees with the diplomas with honors depends on their previous place of study.

Each enrollee was to write multiple choice test in field of Construction Engineering. This test took into consideration not only students' theoretic knowledges, but also their scientific works and publications. The results of the exam showed that graduates from SPbPU showed better results than students from other universities (Fig.5). However, according to the chart it is impossible to make an unambiguous conclusion about the quality of students. Graduates of SPbPU showed the best results due to their publications, while the majority of graduates of other universities did not have them at all.

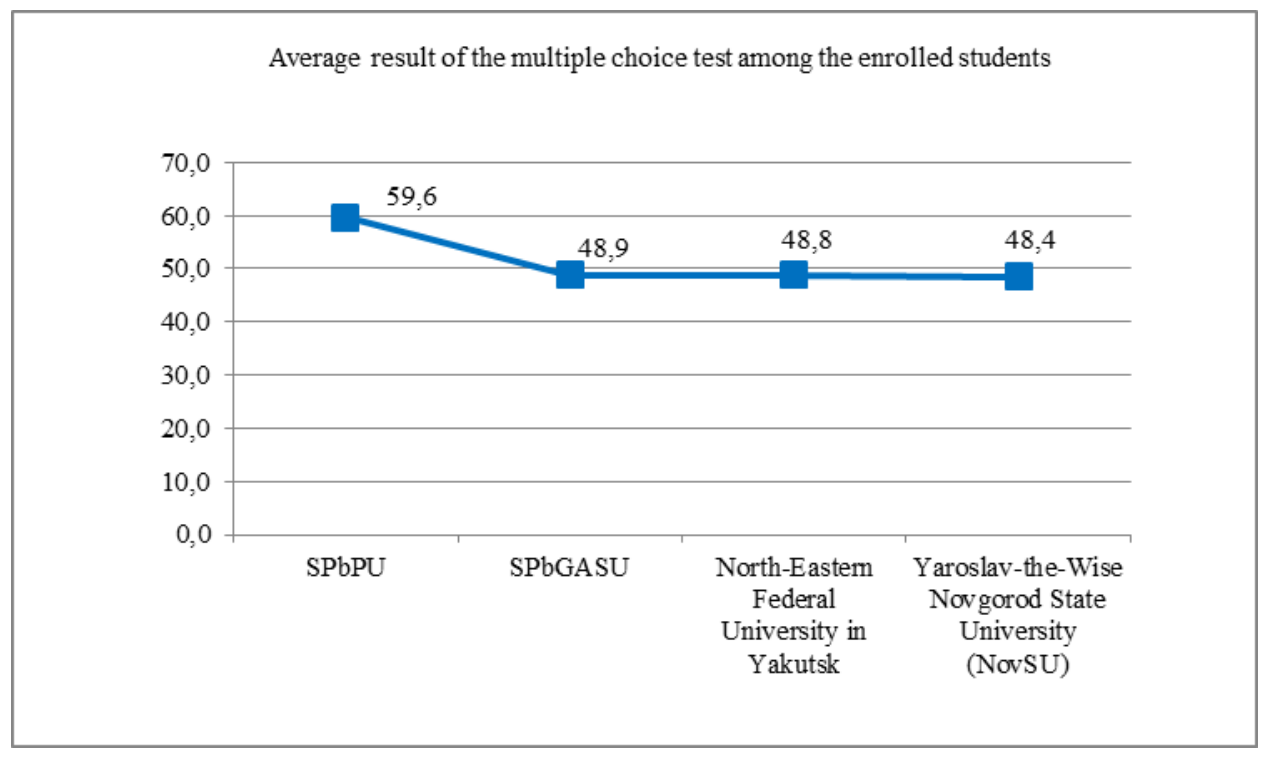

Figure 5. Average result of the multiple choice test among the enrolled students.

The maximum amount of points for the test is 100 points. According to the figure 6 only the graduates from SPbPU wrote the exam and scored above 60 points. Graduates from other universities only have crossed the threshold value of success (40 points) and a some of them got 50-60 points. 


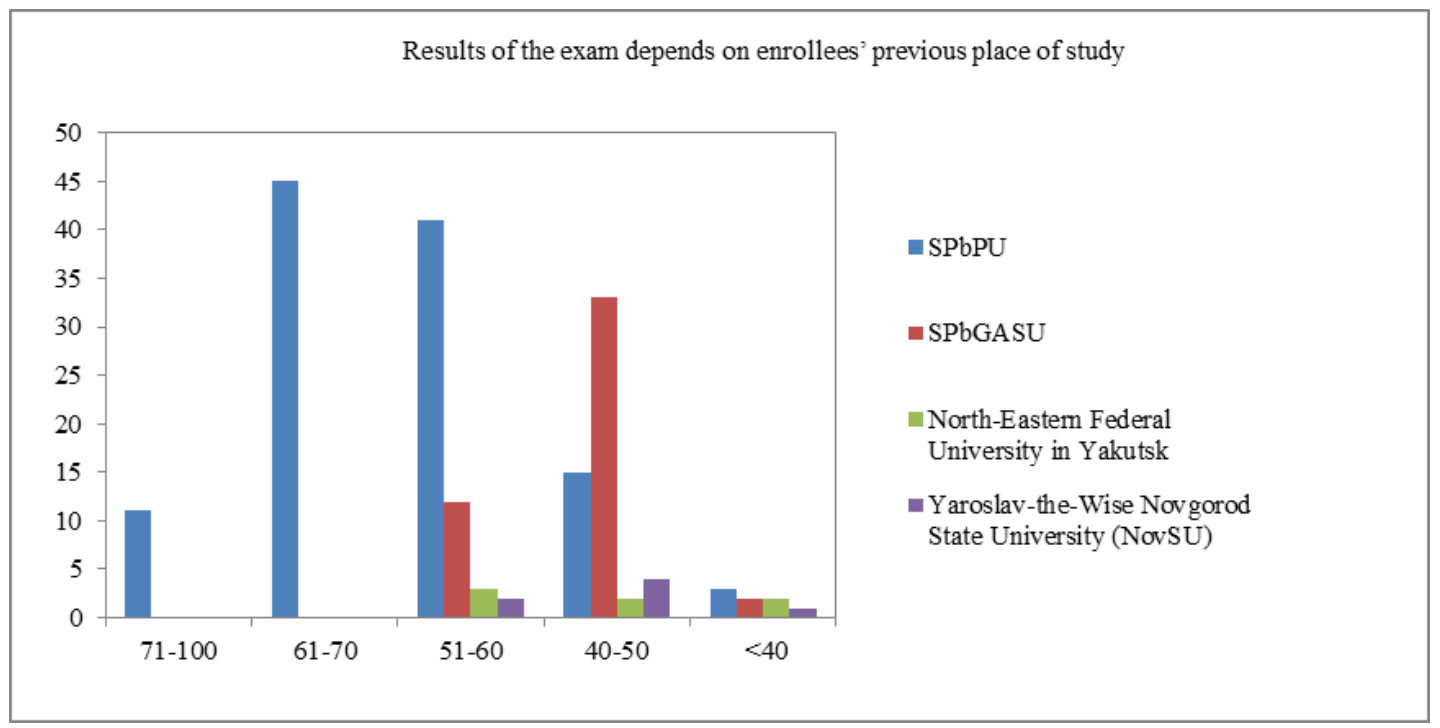

Figure 6. Results of the exam depends on enrollees' previous place of study.

Foreign students are interested in the master's degree program in the field of Constriction Engineering [14]. Primarily, there are citizens of Uzbekistan, Georgia, Iran, Syria, Egypt, China, India and Africa. The division of foreign students into profile programs is showed on the figure 7.

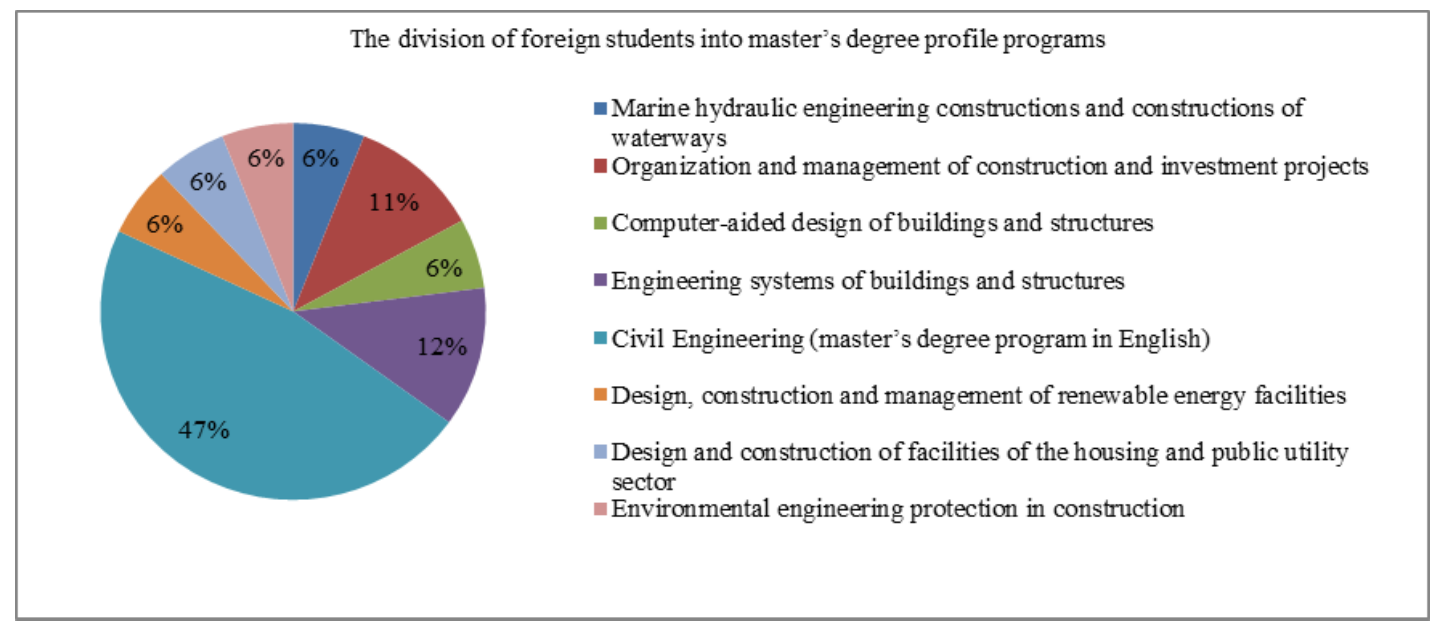

Figure 7. The division of foreign students into master's degree profile programs.

Almost the half of the foreign students (47\%) prefers international master's degree profile program "Civil Engineering". This program is in the English language and it is easier for international students to master the educational program. Nevertheless, in SPbPU for many years the system of training, where foreigners learn Russian language [16]. That is why 53\% of foreign students according to figure 7 are enrolled in master's degree programs in Russian language (fig.7).

\section{Conclusion}

The magistracy provides preparation of scientific and pedagogical staff, helps to identify the ability of students to the research work and thus, to determine the future direction of its activities. A master's degree gives the opportunity to feel confident in life and to find a high-paying job. The Institute of Civil Engineering is the leader in the admission to the master's degree programs in the field of 
Construction Engineering among universities in the Northwestern Federal District of Russia. Graduates from SPbPU enrolling the magistracy of the ICE show the better results than graduates from other universities. International master's degree programs attract foreign students, which improves the position of SPbPU in the world rankings of universities.

\section{References}

1. Wikipedia. Peter the Great St. Petersburg Polytechnic University. Retrieved from http://www.wikipedia.org/

2. Peter the Great St. Petersburg Polytechnic University. Retrieved from $\mathrm{http}: / / \mathrm{www}$. alluniversitycourses.com/

3. Peter the Great St. Petersburg Polytechnic University. Program «5-100». Retrieved from http://5100.spbstu.ru/en/about-program/info/

4. Peter the Great St. Petersburg Polytechnic University. Programs in English. Retrieved from http://eng.spbstu.ru/

5. Civil Engineering Faculty. Retrieved from http://www.cef.spbstu.ru/

6. SPbGASU. Plan of the admission in 2015. Retrieved from http://www.spbgasu.ru/Abiturientam/Priem/

7. The National Mineral Resources University. Plan of the admission in 2015. Retrieved from http://priem-univer.ru/plan-priema

8. St. Petersburg State University of Communication. Plan of the admission in 2015. Retrieved from http://pgups.ru/abitur/pk/plan_priyema/

9. A.V. Rechinskiy, N.I. Vatin, O.S. Gamayunova, K.Y. Usanova, Construction of Unique Buildings and Structures, 2, 6-17 (2012)

10. O.S. Gamayunova, V.V. Ershov, A.A. Iljin, S.I. Li, B.V. Sokolov, Construction of Unique Buildings and Structures, 5, 26-30 (2012)

11. D.G. Arseniev, A.V. Rechinskiy, N.I. Vatin, O.S. Gamayunova, Construction of Unique Buildings and Structures, 2 (17), 5-24 (2014)

12. N.I. Vatin, O.S. Gamayunova, D. Petrosova, Applied Mechanics and Materials, 635-637, 20852089 (2014)

13. N.I. Vatin, O.S. Gamayunova, D. Nemova, Applied Mechanics and Materials, 638-640, 24602464 (2014)

14. D.G. Arseniev, A.V. Rechinskiy, K.V. Shvetsov, N.I. Vatin, O.S. Gamayunova, Applied Mechanics and Materials, 635-637, 2076-2080 (2014)

15. O.S. Gamayunova, N.I. Vatin, Advanced Materials Research, 1065-1069, 2459-2462 (2015)

16. O.S. Gamayunova, K.Y. Usanova, Construction of Unique Buildings and Structures, 7 (12), 10$19(2013)$

17. D.G. Arseniev, A.V. Rechinskiy, K.V. Shvetsov, N.I. Vatin, O.S. Gamayunova, Construction of Unique Buildings and Structures, 8 (23), 21-35 (2014)

18. N.I. Vatin, O.S. Gamayunova, Advanced Materials Research, 1065-1069, 2622-2625 (2015)

19. V. Kolokoltsev, E. Razinkina, The Vysshee Obrazovanie v Rossii (Higher Education in Russia), 5, 3-10 (2011)

20. D.G. Arseniev, N.I. Vatin, Construction of Unique Buildings and Structures, 2, 1-5 (2012)

21. D.G. Arseniev, N.I. Vatin, A.E. Vysotskiy, Construction of Unique Buildings and Structures, 5, $1-5(2012)$ 